\title{
Ekologické myslenie, vzdelávanie a komplexita
}

\author{
Karol Herian \\ Envigogika 2008/III/1 - Recenzované články/ Reviewed Papers \\ Publikováno/Published 21. 05. 2008
}

DOI: http://dx.doi.org/10.14712/18023061.26

\begin{abstract}
Abstrakt:
Do debaty o východiskách a podobách environmentálnej výchovy, dlhodobo prebiehajúcej na stránkach Envigogiky, vstupujeme s ambíciou diskutovat' o formovaní ekologického myslenia ale aj vzdelávacej teórie a praxe $v$ súvislosti $\mathrm{s}$ rozvojom vied o komplexite.
\end{abstract}

\section{Klíčová slova:}

xxxx

\begin{abstract}
:
The article reflects contemporary discussions on formation of ecological thinking and educational theory and praxis, all of which is related to the development of complex sciences - from two points of view: The first deals with ecological thinking with regard to meta-scientific implications of the disciplines dealing with organized complexity; the second concentrates on the relevance and impact of complexity science for transformation processes in the field of education (paradigms and institutions).
\end{abstract}

\section{Key words:}

$x x x x$ 


\section{Úvod}

Túto diskusiu rozvinieme $v$ dvojakom ohl'ade: 1 . budeme uvažovat' o ekologickom myslení, ktoré sa formuje $\mathrm{v}$ kontexte metavedeckých implikácií disciplín o organizovanej zložitosti; 2. sústredíme sa na reflexiu o relevancii vied o komplexite pre transformáciu vzdelávacích systémov a procesov.

O tom, čo znamená ekologické myslenie, aké je, ako mu rozumiet a napokon, ako ekologicky mysliet', máme mnoho rôznych predstáv, neistôt i návrhov. Na tomto mieste budeme uvažovat' o podobe ekologického myslenia, ktorá zodpovedá poznaniu pestovanému na pôde nereduktívnej vedy: poznaniu, ktoré poukazuje na nevyhnutnú jednotu prírody a myslenia (Bateson, 1980), na jednotu života a poznávania skrze organizačnú aktivitu živých systémov (Capra, 2004), na prekonaný rozdiel medzi súcnom fyzikálnym a organickým skrze princíp samoorganizácie a disipatívnych štruktúr (Prigogine, Stengersová 2001, Coveney, Highfield 2003, Barrow 1996). Tieto vedy nás privádzajú k zmenenému chápaniu skutočnosti, "zmenila sa samotná povaha vedy, ktorá dnes odhal'uje hlbšiu, svojbytnú racionalitu - skrytý rád pod chaotickými dejmi, rád prístupný pokornému l'udskému poznaniu, nie však spupnej manipulácii" (Neubauer, 1993).Príroda stratila svoju vypočítatel'nost', je nelineárna, plná fluktuácií, je zložitým celkom, ktorý je výsledkom interakcií nespočetného množstva častí, pričom sa ukazuje, že jej organizácia nie je nepodobná mysleniu a poznávaniu. Ak sa tieto a mnohé d’alšie výpovede nereduktívnej vedy stanú inšpiráciou a východiskom pre ekologické myslenie, tak ono môže byt́ nástrojom pre nereduktívne poznávanie životného prostredia, pre účinnú a zodpovednú environmentálnu teóriu a prax, no súčasne môže byt́ ono aj nápovedou pre laika, súčasného človeka hl'adajúceho orientáciu $v$ stále zložitejšom a neistejšom svete. Dôverujeme tomu, že ak dokážeme $v$ systéme environmentálneho vzdelávania, $v$ rámci rôznych edukačných programov nájst' a vytvorit' podmienky pre kultivovanie ekologického myslenia, tak ako ho tu diskutujeme, ono samé bude mat́ spätný vplyv aj na premenu edukačnej teórie a praxe. Dnes sme svedkami už vyše dekádu trvajúceho úsilia o premenu vzdelávacích programov a systémov práve podla princípov synergetiky, v intenciách metodologických dôsledkov vied o komplexite (Davis et al. 2000, Kindt 2002, Moll et al. 2005, Hanzel 1996).

(Takto na úvod sme si predstavili aj aplikáciu spätnej väzby, ktorej prítomnost́ premieňa jednoduché a deterministické systémy na systémy komplexné až chaotické: vzdelávanie podmieňuje myslenie a to vplýva na zmeny vo vzdelávaní, ktoré vedie k zmenám v myslení, atd'.)

\section{Ekologické myslenie - predporozumenie}

Ekologické myslenie sa väčšinou vníma ako myslenie vzt́ahové, kontextuálne, založené na vnímaní a rešpektovaní závislostí, vzájomných väzieb a usporiadaní celku (Capra 2004,Horká, 2005).

Ekologické myslenie, tak ako ho tu diskutujeme, nevnímame ako "zelený" projekt, nie je ním žiadnou etikou podmienený, žiadnou ideológiou vynútený návrh „korektného" či "ochranárskeho" myslenia, naopak, ekologické myslenie chápeme ako prirodzený dôsledok vývoja civilizácie a nového vnímania prírody a vzt́ahu človeka k nej pestovaného na pôde nereduktívnej vedy.

Samozrejme, celkom oprávnene očakávame, že ekologické myslenie by nám malo byt́ oporou $v$ odborných i laických prístupoch voči životnému prostrediu, pri starostlivosti oň, pri zodpovedaní na vel'mi aktuálne environmentálne výzvy, ale neredukujeme ho iba do takejto podoby. Pod ekologickým myslením nechápeme špecifické, "menšinové" či "okrajové" myslenie smerujúce k zabezpečovaniu ekologicky stabilného sveta - skôr ho 
chápeme ako myslenie zodpovedajúce povahe prírody a mysle, ktoré však nie sú viac objektom a subjektom, ktoré nelinearizujeme, u ktorých rešpektujeme vývoj, samoorganizáciu, celostnost'.

Nechceme a nemôžeme nijako definovat' ekologické myslenie - máme iba predporozumenie, ktoré sa nám stáva východiskom pre diskusiu a neskoršie upresnenia. Ekologické myslenie predovšetkým vnímame ako súčast' myslenia vyvíjajúceho sa od samozrejmosti bytia k dráme „nastávania". Názvov pre toto myšlienkové dianie a východisko môžeme nájst' viacero: Nový dialóg človeka s prírodou - tak ho vnímajú Ilya Prigogine a Isabelle Stengersová (2001), systémová múdrost' - o nej hovorí Gregory Bateson (1978, 1980), ekologická vízia reality a ekologická paradigma podla Fritjofa Capru (2002a, 2002b), alebo jednoducho a predsa výstižne ekologické myslenie - tak o ňom hovorí mimo iných Tomáš Škrdlant (1996). Na tomto mieste však uved'me, nezávisle od názvu, že toto nové myšlienkové prostredie nám pripomína jedno: novoveká vedecká paradigma, ktorá bola predpokladom rozvoja l'udskej civilizácie za posledných tristo rokov je vyčerpaná, prekonaná. Nielen, že popri nesmiernych vedeckých a technických úspechoch priniesla i mnoho deformácií do poznávacích a aplikačných stratégií človeka, ona sa dnes ukazuje už ako neadekvátna pre budúce úsilie človeka rozumiet' sebe a prírode a potom sa v kozme zodpovedne pohybovat'.

Svet poznávaný a manažovaný skrze pohl'ad materialistickej a reduktívnej mechanistickej paradigmy bol uzavretým, univerzálnym a relatívne vypočítatel'ným objektom. Táto istota o našom harmonicky usporiadanom domove vplyvom nového poznania už jedno storočie koroduje a dnes obývame neprehl'adný svet, plný neistoty, chaotickej premenlivosti. Už čoraz naliehavejšie tušíme, že svet nie je statické súcno, je časový a podobný mysleniu, je fluktuujúcim systémom neustále vytvárajúcim nové štruktúry. Nie je viac strojom, je zložitý a plodivý ako život a jeho budúcnost' sa nedá predpovedat'. "Nepredvídatel'né správanie sa (prírodných) systémov získava stále väčšie rozmery, pričom na ich reguláciu nie sme vybavení ani teoreticky. To súvisí s komplexnou povahou týchto systémov, zložitým usporiadaním biosféry a ich (životne dôležitých) funkcií. Interakcie prírodného prostredia so systémami antropogénnymi sú potom charakterizované zvýšenou mierou rizika a tzv. neurčitostou (uncertainty)." (Dlouhá, 2006, s.1) Mnohé minulé poznanie, ktoré sa dalo (dočasne) uplatnit' voči svetu (v novovekej tradícii ako voči objektívnej skutočnosti), sa dnes vo svete diania a procesov bez deterministickej a lineárnej kauzality, javí ako celkom neadekvátne. Človek dnes nie je schopný plne vnímat́ systémovú povahu sveta, nie je k tomu vedený a voči rastúcim problémom globálneho rozmeru ostáva neraz celkom bezradný.

Vedy o organizovanej zložitosti nám ukazujú híbku ale i dôsledky zmien v chápaní sveta, prírody, človeka a života a napokon i v chápaní vedy samej. Tieto disciplíny nás privádzajú k uznaniu konceptuálneho posunu od bytia k nastávaniu, od snahy po stabilite k uznaniu významu nestability, od túžby po poriadku po uznanie chaosu, ktorý generuje nový poriadok prostredníctvom evolúcie štruktúr. Veda objavuje prírodu plnú nelinearít, ale už ju nemusí linearizovat', veda prekonáva disciplinárnu roztrieštenost' v snahe pochopit' život a evolúciu, príroda nie je objektom ale fluktuujúcim procesom, hranice medzi živým a neživým sa stierajú. Vyčerpatel'né poznanie formulované konečnou "rovnicou" je nemožné, determinizmus už viac neznamená predpovedatel'nost'.

Ekologické myslenie formujúce sa $v$ kontexte metavedeckých implikácií disciplín o organizovanej zložitosti sa neprejavuje iba v úzkom pomere človeka voči životnému prostrediu, ale nevyhnutne sa odráža v celej kultúre. Vedie k premene vnímania ale aj konštruovania sociálnej reality ako aj k premenám predstáv a praktík o udržatel'nom rozvoji.

Reagovat' na globálne ohrozenia izolovanými iniciatívami, jedno či politickými alebo ochranárskymi alebo z pozícií jednotlivých vedných disciplín je neprimerané a nezodpovedajúce vážnosti situácie. Svet nie je lineárny, nie je skladačkou, ktorú ak chceme naprávat', je možné postupne vylepšovat́ jej jednotlivé časti. Obývame nelineárny svet, v ktorom sa všetko špecifické poznanie relativizuje a preto musíme byt' ovel'a 
skromnejší. Nástroje novovekej vedy sú stále platnými nástrojmi v izolovaných sústavách Zeme, ale pre zodpovedný pobyt na celku planéty musíme ustúpit́ z pozícií manažérov objektívneho súcna, skôr do polohy angažovaných účastníkov komplexných dejov $\mathrm{s}$ otvoreným koncom. A velkou výzvou v tejto pomerne novej situácii človeka na Zemi je pochopenie komplexity.

\section{Zložitost' životného prostredia a vedy o organizovanej zložitosti}

Pri každom štúdiu problémov životného prostredia vychádzame z poznania o zložitých vzájomných a netriviálnych súvislostiach medzi prvkami prírodného prostredia a javmi a procesmi v oblasti hmotnej i duchovnej kultúry. Situácia človeka na Zemi je v súčasnosti neprehl'adná i preto, že sme sa stali obyvatel'mi globálnej civilizácie: l'udia, kultúry a časti biosféry sú v nových a nezvratných globálnych väzbách, vznikli historicky bezprecedentné vzt́ahy a závislosti medzi jednotlivcami, spoločnostáami a ekosystémami $\checkmark$ rámci celej planéty. Zem a jej prírodné a sociálne systémy, celá hierarchia podsystémov rôznej úrovne a rôznej previazanosti je procesom $v$ neustálych sebapremenách (ktorých je človek integrálnou súčastou) a predstavy o deterministických pravidlách, jednoznačnom riadení a vypočítatel'nosti dejov už neplatia. Životné prostredie $v$ súčasnom porozumení vnímame skôr ako zložitý a nepredpovedatel'ný dynamický systém, ako fluktuujúce a vnútorne sa organizujúce dianie.

Príroda i kultúra, civilizácie, ludské spoločnosti sú vel'mi komplexné a ich zložitost́ sa neustále zvyšuje. Prehlbovanie interakcií kultúry s prírodou, rast výroby, služieb a aktivít všetkého druhu spolu s rastom prenosu informácií na všetkých úrovniach spoločnosti, medzi jednotlivcami, inštitúciami a riadiacimi centrami pridávajú do l'udských spoločností nesmierne množstvo nelineárnych vzt́ahov a spätnoväzobných slučiek. Komplexita ludských spoločností sa neustále prehlbuje a spolu s tým sa prejavujú všetky dôsledky: možnost' vzniku emergentných vlastností a kvalít, nové možnosti samoorganizácie ale i citlivost́ na fluktuácie či nepredpovedatel'nost' d’alšieho vývoja globálnej civilizácie. Súčasná situácia globálneho l'udstva sa môže vyvinút smerom k dezorganizácii, neporiadku a náhodnosti ako i smerom $\mathrm{k}$ usporiadanosti a rádu, pričom tieto možnosti nemôžeme posudzovat́ tradičnými etickými kategóriami. Poriadok môže ale i nemusí priat' udržatel'nému rozvoju, rovnako ako chaos môže byt́ ničivý i tvorivý.

Jednou z možností, ako neredukovane vnímat', mysliet́ a napokon i riešit reálne javy a problémy nášho sveta, je „pristupovat" $\mathrm{k}$ ním ako ku systémom, resp. uplatňovat' systémový prístup. Na javy a predmety skúmania nazeráme nie ako na objekty či súbory prvkov ale ako na usporiadané celky $v$ ich vnútorných a vonkajších súvislostiach. „Systémový pohlad vidí svet na základe vztáahov a integrácie." (Capra, 2002a, s.294)

Ďalší posun $v$ chápaní systémov a ich správania sa priniesli $v$ posledných desat́ročiach synergetika, vedy o komplexite, teória chaosu. Štúdie o organizovanej zložitosti, disciplíny zaoberajúce sa vysokoorganizovanými systémami, resp. živými systémami, disipatívnymi štruktúrami nás stavajú pred fakt, ktorý z pozície humanitných vied ohlasovali filozofi, lingvisti a antropológovia: samozrejmost' bytia nahrádza dráma „nastávania" (Prigogine, Stengersová 2001).

V súčasnosti prebiehajúca zmena paradigmy dozrievala dlho a dnes sa môže stat́ základom dialógu človeka s prírodou, zavíšením pádu mechanicizmu a nádejnou situáciou, ked' "veda hovorí s prírodou, ale už nepredvádza výsluch."(Havlík, 1995, s.89) Prigogine dodáva: „Existuje ale ešte jedna príčina, ktorá ma presviedča, že teraz prežívame rozkvet vedeckej revolúcie. Klasický (často nazývaný 'galileovský') prístup k vede vyžaduje, aby sme skúmali svet ako nejaký 'objekt' a snažili sa tak popisovat' fyzikálny svet zvonku, analyzovat' ho, ale nepatrit' k nemu. Skôr bol tento prístup neobyčajne úspešný, teraz sme dospeli až k jeho hraniciam." (cit podla Havlík, 1995, s.85) 
Do sveta novovekej vedy, analýzy zložiek prírody, elementárnych častíc, genetickej determinácie vstupuje evolúcia, nevratnost', komplexita a nevypočítatel'nost́. Veda rozvíja koncepcie "organizovanej komplexity", skúma schopnosti živých organizmov udržovat' svoje životné procesy za nerovnovážnych podmienok, študuje vznik disipatívnych štruktúr, rádu, sebautváranie a priznáva zmenenú úlohu subjektu poznávania. Veda a poznávanie nemôžu viac stát na izolovaných predpokladoch, na akoby zvonku prírody a života danej metodológii, ale musí „zodpovedat́ charakteristickým vlastnostiam života." (Havlík, 1995, s.88) Navyše sa nedá prehliadat́ ani zložitý vzájomný vztáah medzi pravidlami vedeckej hry a kultúrnou sférou, ku ktorej vedec nevedome patrí. Súčasná veda skrze odhalenie komplexity odhaluje jednotu človeka ako indivídua i spoločenskej bytosti a prírody a tým vymedzuje i pravidlá pre seba samú, odhaluje vlastnú historickú podmienenost' (Havlík, 1995).

Štúdium komplexity - ktorá je nevyhnutne prítomná v povahe evolúcie, vývoja prírody, živých organizmov i človeka - nám dáva možnosti študovat' problémy, ktoré sa zdali dosial' nezvládnutel'né. Môžeme poznávat', simulovat' i ovplyvňovat' technické a prírodné systémy, sociálne fenomény, chod ekonomiky, fungovanie mozgu, či plnšie rozumiet' a formovat' verejnú správu, vzdelávanie a podobne. Synergetika, štúdia komplexity a teória chaosu nám otvárajú pohl'ad na svet a náš život z novej perspektívy - v nej sú tradičné predstavy a živote a hmote, samoorganizácii a vývoji, predstavy zákonitosti a o náhode prekonané. Musíme si na túto perspektívu zvyknút, lebo i miesto a úlohy človeka v organizácii života sú nové a vyžaduje to od neho nový typ dialógu so spoločnostou i prírodou.

„Doba epistemologických ilúzií, ktoré vedcov izolovali a stavali mimo prirodzený svet, pomaly končí," ohlasujú Prigogine so Stengersovou. "Protiklad medzi priezračnost́ou vedeckých popisov a nepriehladnostou podmienok jeho možností tak mizne, takže môžeme v prekonaní novovekých kategórií reprezentácie a protikladu subjekt-objekt mysliet́ podstatnú prináležitost́ vedy k celku vznikajúcej prírody, definovanej ako to, čo kladie problémy." (cit podla Havlík, 1995, s.86)

V intenciách tohto posunu vo vede sa čoraz nástojčivejšie žiada aj zmena v kultúre, v spôsobe myslenia a nazerania na človeka a svet - obrat od novovekého panského postoja presadzujúceho sa indivídua smerom k postoju ekologickému. Takýto postoj vychádza z rozpoznanej jednoty prírody a mysle.

\section{Vedy o zložitosti a edukácia}

Ak sme doteraz diskutovali o vedách o organizovanej zložitosti $v$ súvislosti s charakterom životného prostredia a potom obecne o ich metavedeckých implikáciách pre formovanie ekologického myslenia, teraz si budeme všímat', nakolko môže byt́ komplexita relevantnou inšpiráciou pre edukačnú teóriu a vzdelávaciu prax.

Vedy o komplexite sa od svojho počiatku uplatňovali predovšetkým pri popise, chápaní a interpretácii nelineárnych systémov fyzického charakteru. Formovali sa najprv na pôde matematiky, chémie, fyziky a postupne nachádzali uplatnenie $v$ medicíne, pri výskume mozgu, v počítačových vedách či robotike. Až neskôr sme mohli sledovat ich zhodnotenie a aplikácie $v$ sociálnych vedách a humanitných odboroch. Koncepty $z$ teórie komplexity sa presadili pri štúdiu ekonomiky, v podnikovom manažmente, v ekológii, pričom ich poznanie nás privádza k odhaleniu evolučných kríz, sociálnej či politickej nestability (Byrne, 1998). Vnímanie komplexity resp. chaosu ovplyvňuje názory sociálnych vedcov a politikov na príčiny výskytu rôznych sociálnych javov, konfliktov, vojen a rovnako ako pomáha rozumiet' ludskej tvorivosti, zdraviu, sociálnej komunikácii, napomáha uskutočňovat' aj vhodnú terapiu.

$\checkmark$ poslednej dekáde 20. storočia sa začala diskusia aj o relevancii vied o komplexite pre výchovu a vzdelávanie. Táto diskusia sa rozvíja dodnes: sú autori, ktorí od počiatku rozpoznávali a obhajovali potenciál vied o komplexite pre edukačnú teóriu a prax (Davis et 
al. 2000, Kindt 2002, Moll et al. 2005, Osberg et al. 2008), no súčasne registrujeme aj hlasy skeptické (Hunter, Benson 1997, Jorg 2005).

Motívov pre "angažovanie" komplexity do edukačnej sféry je mnoho, no medzi primárne určite náleží poznanie o neprimeranosti prevažujúcich prístupov vo vzdelávaní, v oblasti teoretickej i aplikačnej. Vzdelávanie, ktoré je založené na vedeckom poznávaní sveta a naň sa odvoláva, sa reálne uskutočňuje $v$ kontexte redukcionistických predstáv o povahe sveta a miesta človeka $v$ ňom, v kontexte (možno už nevyslovených ale prítomných) predpokladov akými sú linearita, determinizmus, vypočítatel'nost' hierarchicky usporiadaného súcna, autorita metód vzdelávacieho procesu, uzavretost́ systémov - plánovanie a realizácia učebných programov nezávislé od kontextov, kumulatívne chápanie poznávania a podobne. Kratochvíl (1995) upozorňuje, že stále sa môžeme stretnút s chápaním vzdelávania ako procesu, technológie, ktorú je možné a potrebné optimalizovat́. Pinc (1999) píše o fungovaní školy ako úradnej mašinérie školského systému, ktorá plní pastoračno-disciplinačnú úlohu a slúži predovšetkým pre zdisciplinovanie nastupujúcich generácií. Vo sfére vzdelávania akoby pretrvávali inštinkty utvrdené počas dlhého pobytu mnohých generácii $v$ mechanisticky vnímanom svete: inštrumentálny prístup k žiakom, učitel'om a poznaniu (to sa zúžilo do reprodukovatel'ných poznatkov), nereflektovaná viera v triviálnu kauzalitu príčiny a následku, redukcia vzdelávania do procesov s definovanými vstupmi, výstupmi a procedúrami, ktoré je možné jednoznačne riadit' a hodnotit'.

Súčasne s pretrvávaním podobných tendencií vo vzdelávacej praxi sme svedkami aj ich dôslednej reflexie a kritiky - pedagogické myslenie i prax sa vyvíjajú, a na tomto mieste chceme ukázat', že do transformačných pohybov vo vzdelávaní sa dnes vstupuje aj z pozícií vied o organizovanej zložitosti. "Nové porozumenie, ako môže byt' svet zmapovaný prostredníctvom komplexity, môže poskytnút produktívne a významné príležitosti pre vzdelávanie." (Laidlow, 2004, s.3) Marshallová argumentuje, že je užitočné uvažovat' o školstve a vzdelávaní v kontexte rozvoja nereduktívnych vied a vtedy "musíme nazerat' na naše školy, triedy a učitel'skú prácu celkom odlišne, ponovom. Musíme ich vidiet ako dynamické, adaptívne a samo-organizujúce sa systémy, ktoré sú inherentne nadizajnované smerom k sebaobnove, ktoré sú schopné vyvíjat' sa. Ale nie vyvíjat' sa podl'a zhora predpísaných pravidiel, ale prostredníctvom vzt́ahov vytváraných vo vlastnom prostredí." (Marshall, 1996, s.4) V takejto optike sa vzdelávanie ukazuje ako dynamický a organický systém.

Linda Laidlow píše, že podobne ako väčšina učitel'ov, aj ona po absolvovaní univerzity $v$ školskej praxi pochopila, že jasným a úhl'adným schémam a ilustráciám, lineárne krok-po-kroku vystavaným procedúram a didaktickým inštrukciám chýba čosi vitálne - terra incognita, neznámy priestor, ktorý akoby nikdy neexistoval na mapách pedagogiky. (Laidlow, 2004) Stáva sa často, že zatial' čo pedagogické štúdia pripravujú budúcich učitel'ov pre metodicky záväzné fungovanie v škole, v praxi sa vzdelávanie uskutočňuje ináč - vzdelávanie nie je vypočítatel'ným systémom, ono sa ukazuje ako živé, premenlivé, náhodné a nevypočítatel'né. Pedagógom náhle chýba slovník, metóda, vedecké rozpoznanie či uznanie "živosti" systému, jeho tekutosti, vývoja, nepredpovedatel'nosti a v tejto situácii rámec pre vhl'ad, porozumenie a vysvetlenie dejov ponúkajú vedy o komplexite.

Ako sme spomínali, skúsenost' a vedomie o nevypočítatel'nosti, neurčitosti a nelineárnosti vo vzdelávacích procesoch viedlo $\mathrm{k}$ tomu, že niektoré podstatné určenia pedagogiky a vzdelávania je možné artikulovat' prostredníctvom komplexity.

Všimnime si túto skutočnost' pohl'adom na niekol'ko najdôležitejších konceptov vied o organizovanej zložitosti vo vzt́ahu k vzdelávaniu: nelinearita, nepredpovedatel'nost', emergencia, chaos, malé zmeny vedúce k velkým dôsledkom.

Predovšetkým, proces formálneho vzdelávania v školskom prostredí chápeme ako komplexný systém, dynamický a adaptívny, charakterizovaný samo-organizačnými 
tendenciami, schopný vytvárat' emergentné kvality. Vzdelávanie je otvoreným systémom, otvoreným voči prostrediu a toku hmoty, energie a informácií, a to má význam pre jeho adaptáciu ale i evolúciu. Ako komplexné učiace sa systémy, vzdelávacie procesy a školy sú ovel'a viac organické a dynamické než lineárne (Marshall, 1996, s.4), sú charakteristické prítomnost́ou spätných väzieb, ktoré niektoré javy posilňujú, iné utlmujú, tým sa eliminujú jednoduché kauzálne vztáahy a v stave nestability či chaosu môžu vznikat' nové usporiadania a kvality. Z takejto perspektívy školu a vzdelávanie nevnímame ako uzatvorený systém, lineárny a deterministický, ale skôr ako príbeh s otvoreným koncom. (Samozrejme, v pedagogickej teórii i v "školskej prevádzke" stále registrujeme množstvo linearít - vo vzt́ahu učitel'-žiak, v podobe realizácie učebného plánu, v časovej následnosti učiva a podobne, no ukazuje sa, že ony sú novovekým metodickým nástrojom redukujúcim nutne prítomnú komplexitu. Alternatívou voči takejto linearite sú vzdelávacie prístupy založené na dialógu, komunikácii, motivácii, samoštúdiu, spolupráci a podobne.) Nelinearita komplexného systému (založená na sieti kladných a záporných spätných väzieb) spôsobuje to, že systém nie je deterministicky vypočítatel'ný, prejavuje sa nečakanými interakciami, náhodnostou. V takej situácii edukačné procesy vzdorujú jasnému riadeniu - $v$ kontraste $s$ túžbou po jasnom programe, curriculum, výstupoch - a neraz lepšie než metodické procedúry sa uplatní improvizácia.

Podobne ako na emergenciu nových kvalít v komplexnom systéme môžeme nazerat' na učenie sa, na rast porozumenia, pochopenia a vedomostí. Vzdelávanie takto neredukujeme do aplikácií lineárnych procedúr ( $v$ krajnom prípade až transferu dát a poznatkov), ale môžeme mu rozumiet' ako ako emergentnej kvalite vznikajúcej $v$ rámci a medzi vztáahmi samoorganizujúceho sa komplexného systému (Laidlaw, 2004).

Podobne aj známu skúsenost' vzdelávania podmieneného prítomnostou človeka v tvorivom, resp. inšpirujúcom kolektíve, môžeme vysvetlit́ prostredníctvom emergencie: je to také porozumenie vznikajúce $v$ skupine, skrze interakcie, ktoré nemôže vzniknút' pri samoštúdiu. Vzdelávanie rastúce ako kvalita v rámci emergentného edukačného prostredia nie je podmienené len zvonku vytvoreným prostredím a didaktickými procedúrami nezávislými na záujmoch a konaní prítomných l'udí. Učitelia a žiaci sa nevyhnutne zúčastňujú na štruktúre systému a tak modifikujú jeho štruktúru, priebeh, smerovanie, zohl'adnením ich konania rastie zložitost' systému, ten často môže vykazovat́ znaky chaosu, môžu v ňom vznikat' nové usporiadania.

Trieda, školský kolektív nie je triviálnym, vypočítatel'ným a riaditel'ným systémom, ako to niekedy môže vyzerat' pri pohl'ade na školské osnovy, rozvrhy a učebné plány. Každý kolektív pozostáva $z$ „jednotlivcov, ktorí sú previazaní na vonkajší svet, navzájom medzi sebou a tiež $k$ nastávajúcim udalostiam. Študenti sú $v$ neustálom procese redefinovania týchto väzieb." (Kindt et al.1999, s. 240) Takýto kolektív je vel'mi dynamický a rovnaké procedúry $v$ rôznom čase môžu viest' aj $k$ celkom odlišným situáciám. Súčasne skúsenost' mnohých učitel'ov potvrdzuje, ako môžu malé zmeny ( $\mathrm{v}$ triede ako v komplexnom systéme plnom nelinearít) viest' k nepredpovedatel'ným dôsledkom. A tieto zmeny a indeterministické deje (napr. jeden nevýrazný študent s novou motiváciou ovplyvní správanie sa celej triedy, malá zmena iniciuje nečakané procesy) je možné chápat́ a interpretovat' skrze teóriu chaosu, zjednodušene prostredníctvom metafory o efekte motýlieho krídla. V takejto situácii, píše Ron Iannone, „umenie práce dobrých učitelov spočiva $\mathrm{v}$ akceptovaní chaotickej povahy triedy $\mathrm{z}$ momentu na moment. Dobrí učitelia alebo dobrí tvorcovia učebných plánov sú ako jazzoví hráči, ktorí musia odpovedat' na nečakané zmeny a improvizovat́ pri tvorbe svojej hudby. Ako hrajú, implicitne alebo explicitne, rozpoznávajú a nachádzajú poriadok v neporiadku." (Iannone,1995, s.3)

Diskusia o relevancii vied o komplexite vo vzdelávaní je otvorená a živá. Popri rastúcom počte prác obhajujúcich miesto a význam komplexity a teórie chaosu v edukácii zaznievajú aj spochybňujúce názory. Podl'a nich komplexita a chaos skutočne vedecký prínos pre edukačnú teóriu nepriniesli a skôr ponúkajú iba podnetnú metaforu a užitočný slovník. Hunter s Bensonom (1997) ukazujú, že teória chaosu nebola vytvorená s úmyslom vysvetl'ovat' l'udské správanie a obhajcovia teórie chaosu preceňujú jej možnosti pre chápanie edukačných procesov. Ton Jorg argumentuje, že mnohé doterajšie úsilie 
aplikovat' teórie komplexity do edukačnej sféry je celom nedostatočné. Výsledky sú iba deskriptívne, vágne a nevedú k reálnym zmenám vo vzdelávaní, navyše, mnohé úvahy o mieste komplexity vo vzdelávaní nemajú dôsledne vedeckú podobu (Jorg, 2005). Samozrejme, diskusia je ovel'a bohatšia, neustále sa vyvíja a jej sledovanie môže byt́ zaujímavé pre všetkých, ktorým na teórii ale i praxi vzdelávania záleží. Rozhoduje sa o tom, či zužitkovanie vied o organizovanej zložitosti pre vzdelávanie bude možné nachádzat́ nielen na epistemologickej ale aj na ontologickej úrovni.

\section{Záver}

Predchádzajúce úvahy o ekologickom myslení a vzdelávaní sme sa pokúsili načrtnút na horizonte nového poznania formulovaného $v$ mnohých odboroch vied o zložitosti. Tieto vedy (zaoberajúce sa štúdiom zložitých, vysokoorganizovaných systémov, resp. živými systémami, disipatívnymi štruktúrami, samoorganizáciou, termodynamikou nerovnovážnych stavov, deterministickým chaosom) významne prispeli k zmene chápania živých ale i neživých systémov smerom od samozrejmosti bytia k dráme "nastávania".

Ukazuje sa, že dnešné poznávanie sveta a jeho subsystémov neprináša stále jasnejšie a hlbšie poznanie súceho a už vôbec nás nepripravuje na bezpečný manažment reality, ale skôr naopak: čím viac svet poznávame, tým viac sa prehlbuje jeho zložitost́ a tým rastie i počet tém a otázok. Podobne stav a vývoj životného prostredia $v$ globálnom rozmere sa každým hlbším poznávaním stáva stále neurčitejším a menej predpovedatel'ným. Budúcnost́ nie je jednoduché predikovat', komplexita nám ukazuje, že budúcnost́ môže ovplyvnit' surprise scenario, ked' v zložitom systéme môže dôjst' k celkom nečakaným výkyvom a zvratom. Nielen prírodné systémy ale i sociálnu realitu charakterizujú nestálost', nevratnost', nerovnováha a nelineárne vztáahy, ktoré umožňujú to, že malé vstupy a zmeny môžu v konečnom dôsledku vyvolat' rozsiahle následky. Novoveký ideál poriadku, usporiadania a riadeného vývoja $v$ prírode i spoločnosti je konfrontovaný s poznaním o fluktuujúcej a nevypočítatel'nej povahe súceho, o pluralite právd, a dokonca o tvorivej povahe chaosu.

Tento premenlivý a neurčitý svet nie je možné úplne poznat' (nie však preto, že nepoznáme všetky jeho prvky a zákony, ale že sa prejavuje ako „živý", premenlivý, fluktuujúci, sebaorganizujúci) a predsa, ak nechceme rezignovat' na vedomé a aktívne úsilie o "riadenie" l'udskej civilizácie smerom k jej udržatel'nému vývoju na planéte Zem, musíme na zložitú situáciu múdro reagovat'. To vyžaduje prípravu, poznanie, nereduktívne myslenie - a práve v tejto situácii hovoríme o ekologickom myslení.

Boli sme zvyknutí mysliet' reduktívne a lineárne: zjednodušujúco a priamočiaro (Škrdlant, 1996). Pre poznávanie a užívanie sveta, ktorý je mechanizmom, neživou sústavou prvkov s kauzálnymi vysvetleniami, ani iné myslenie nie je potrebné. Avšak vnímat' a zodpovedne obývat' svet, ktorý sa v pohl'ade najnovšej vedy ukazuje ako proces, nevratný dej, navyše nie celkom predpovedatel'ný, to vyžaduje nové postoje. Zložitosti sveta a problematiky životného prostredia musí zodpovedat́ myslenie - tu ho nazývame ekologickým.

A dokonca, ako argumentuje Škrdlant, ekologické myslenie implikuje, že "nazeranie na skutočnost' v jej vztahahoch mení túto skutočnost', mení môj vztáah k nej a aj mňa ako jej čast'." (Škrdlant,1996, s.29)

Ak by sa aj školský a vzdelávací systém vyvíjal v kontexte poznania formovanom na pôde nereduktívnych vied, môžeme živit' nádej, že bude lepšie zodpovedat' povahe súčasného sveta a že prispeje k rozvoju ekologického myslenia. Ono by sa neprejavovalo výhradne vo vzt́ahu človeka k životnému prostrediu, formovalo by myslenie a konanie osobnosti vcelku, podmieňovalo by jeho nazeranie na realitu - a súčasne so zmenou jej 
vnímania, reflektovania, menili by sa východiská pre výchovu, vzdelávanie, školstvo. (A tak sme opät' zopakovali postup spätnoväzobného cyklu z úvodu článku.)

Vzdelanost' nás i našich detí nemenej ako so školou súvisí s podobou prírodného a sociálneho prostredia, v ktorom žijeme. Samozrejme, takto môžeme uvažovat' iba vtedy, ak pod vzdelávaním nerozumieme púhe získavanie a reprodukciu zručností a znalostí ako čohosi, čo sa dá tak či onak uplatnit' a čoho úroveň chceme kvantifikovat ako tovar. Ak ale vnímame vzdelanost' ako l'udskú kvalitu, potom sa nedá nijako garantovat' - je emergentnou vlastnostou vyrastajúcou z komplexných otvorených systémov, na ktorých sa vedome zúčastňujeme. Vzdelanie sa nedá získat' či odovzdat,, nedá sa naplánovat', zmanažovat', ocenit'. Vzdelanost' viac ako otázkou školských budov a programov, osnov a didaktík je otázkou ludského dozrievania, rastu, kritického myslenia aj vo vzt'ahu k sebe, je otázkou osobnej orientácie v rôznych svetoch a diskurzoch na horizonte vlastného uvedomovania sa ako človeka so zodpovednostou. Vzdelávanie sa viac podobá na pestovanie ako produkovanie. Vzdelanost' je ako subtílny plod, ktorého rast, chut' ale i schopnost' d'alšej reprodukcie je daná širokou splet́ou podmienok. Je však velkým paradoxom, že ked' chceme týmto podmienkam rozumiet', vyžaduje to opät' vzdelanost'. A napokon, ona vzdelanost' nás nabáda nemat́ plané nádeje ohl'adom každej transformácie vzdelávania, no súčasne nás povzbudzuje k tomu, aby sme nerezignovali na vytváranie podmienok, ktoré pestovaniu vzdelanosti prajú.

\section{Literatúra}

- $\quad$ Barrow, J. D. (1996). Teorie všeho. Praha: Mladá fronta.

- Bateson, G. (1978). Steps to an Ecology of Mind. New York: Ballantine.

- Bateson, G. (1980). Mind and Nature: A Necessary Unity. New York: Bantam.

- $\quad$ Byrne, D. (1998). Complexity Theory and the Social Sciences. London: Routledge.

- $\quad$ Capra, F. (2002). Bod Obratu. Praha: Mat'a.

- Capra, F. (2002). The hidden connections: A science for sustainable living. New York: Doubleday.

- Capra, F. (2004). Tkáň života. Praha: Academia.

- Coveney, P., \& Highfield, R. (2003). Mezi chaosem a rádem. Praha: Mladá fronta.

- Davis, B., Summara, D., \& Luce-Kepler, R. (2000). Engaging minds: Learning and teaching in a complex world. Mahwah: Lawrence Erlbaum.

- Dlouhá, J. (2006). Environmentální vzdělání - pokus o systematické pojmenováni problému. Envigogika, 1(1), Retrieved from http://www.envigogika.cuni.cz/index.php/Envigogika/article/view/7

- Hanzel, P. (1996) Vzt'ah synergetiky k pedagogickým systémom. In Vysokoškolská príprava učitel'ov. Zborník z vedecko-pedagogickej konferencie s medzinárodnou účast'ou. 2. Čast' (pp. 233-236). Banská Bystrica: Pedagogická fakulta UMB.

- Havlík, V. (1995). Synergetika. Návrat ke světu přírodních procesů. Praha: Filosofia.

- Horká, H. (2005). Ekologická dimenze výchovy a vzdělávání ve škole 21. století. Brno: MU.

- Hunter, W. J., \& Benson, G. D. (1997). Arrows in time: the misapplication of chaos theory to education. Journal of curriculum studies, 29(1), 87-100.

- Iannone, R. (1995). Chaos theory and its implications for curriculum and teaching. Education, 115(4), 541. $\quad$ Retrieved http://www.findarticles.com/p/articles/mi qa3673/is 199507/ai n8731833 
- Jorg, T. (2005). Growing Awareness and Sadness. SIG Newsletter, Retrieved from http://www.ccaerasig.com/library/Fall00.htm

- Kindt, D., Cholewinski, M., Kumai, W., Lewis, P., \& Taylor, M. (1999). Complexity and the language classroom. Academia: Literature and Language, 67, 235-258.

- Kindt, D. (2002). Towards a complex systems view of course design. Nagoya University of Foreign Studies Journal of the School of Global Business and Economics, 10, 281-323.

- Kratochvíl, Z. (1995). Výchova, zřejmost, vědomí. Praha: Herrmann a synové.

- Laidlaw, L. (2004). On the Importance of Little Details: Complexity, Emergence and Pedagogy. Educational Insights, 9(4), Retrieved from http://www.ccfi.educ.ubc.ca/publication/insights/v09n01/articles/laidlaw.html

- MARSHALLI, S. P. (1996). Giving wings to new ideas. Wingspread Journal, Retrieved from http://www.johnsonfdn.org/summer96/chaos.html

- Moll, W. F., Fleener, M. J., Trueit, D., \& Julien, J. (eds.), (2005). Chaos, complexity, curriculum and culture: A conversation. New York: Peter Lang.

- $\quad$ Neubauer, Z. (1993). Poručíme větru, dešti. Vesmír, 72(1), 48-49.

- Osberg, D. C., \& Biesta, G. J. J. (2008). From representation to emergence: Complexity's challenge to the epistemology of schooling. Educational Philosophy and Theory, 40(1), 213227. Retrieved from http://www.tandfonline.com/doi/abs/10.1111/j.14695812.2007.00407.x http://dx.doi.org/10.1111/j.1469-5812.2007.00407.x

- $\quad$ Pinc, Z. (1999). Fragmenty k filosofii výchovy. Praha: Oikoymenh.

- Prigogine, I., \& Stengersová, I. (2001). Řád z chaosu. Nový dialog člověka s prírodou. Praha: Mladá Fronta.

- Škrdlant, T. (1996). Demokracie př́rody. Praha: Originální Videojournal. 
Časopis Envigogika vydává Centrum pro otázky životního prostředí UK. Vývoj časopisu je podpořen projektem OP VK Mezioborová sít udržitelného rozvoje.

Více najdete na internetových stránkách projektu mosur.czp.cuni.cz
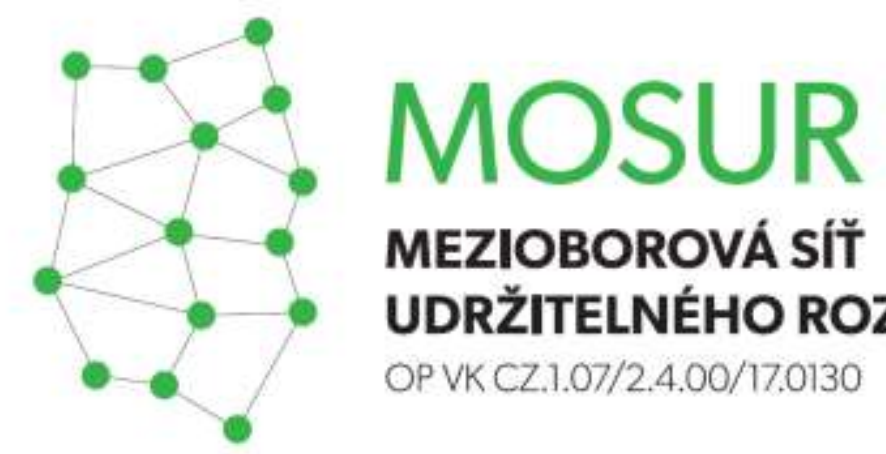

\section{MEZIOBOROVÁ SÍT} UDRŽITELNÉHO ROZVOJE

OP VK CZ.1.07/2.4.00/17.0130
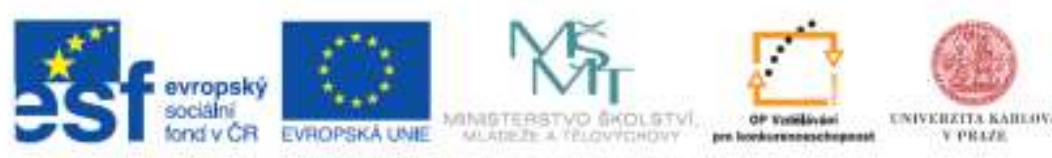

INVESTICE DO ROZVOJE VZDELAVANI 